\title{
Modern Approaches to the Study of Medicines Used in the Treatment of Patients Diagnosed with Covid-19
}

\section{Enfoques modernos para el estudio de los medicamentos utilizados en el tratamiento de pacientes diagnosticados con Covid-19}

\author{
Gulnara Ramazanovna Gamzatkhanova \\ Astrakhan State Medical University 414000 121, Bakinskaya street, Astrakhan, Russia \\ ORCID:0000-0003-2245-8816 \\ Seda Beslanovna Bamatgiriyeva \\ Astrakhan State Medical University 414000 121, Bakinskaya street, Astrakhan, Russia
} ORCID: 0000-0002-7528-9078

Vitaly V. Goncharov

Kuban State Agrarian University named after I. T. Trubilin, Russia

ORCID: 0000-0003-3029-4727

Yana Paromova

Tyumen State Medical University, Tyumen, Russian Federation ORCID:0000-0002-2490-072X

Ivan Gennadievich Subbotin

Saratov State Agrarian University Named after N. I. Vavilov, Saratov, Russia ORCID:0000-0002-9436-0685

Alexander Sergeevich Bronnikov

Kirov Regional State Budgetary Healthcare Institution, 42 Vorovsky str., Kirov, 610027, Russia ORCID:0000-0003-3634-4414

* Correspondence

Email: Gamzatkhanova@yandex.ru

\section{Citation:}

Gulnara Ramazanovna Gamzatkhanova, Seda Beslanovna
Bamatgiriyeva, Vitaly V. Goncharov, Yana Paromova, Ivan Gen-
nadievich Subbotin, Alexander Sergeevich Bronnikov. (2021).
Modern Approaches to the Study of Medicines Used in the Treat-
ment of Patients Diagnosed with Covid-19. Propósitos y
$\begin{aligned} & \text { Representaciones, } \\ & \text { http://dx.doi.org/10.20511/pyr2021.v9nSPE3.1142 }\end{aligned}$




\begin{abstract}
The new coronavirus (COVID-19) was first detected in the city of Wuhan in China in December 2019. Most patients infected with COVID-19 had clinical manifestations of dry cough, fever, shortness of breath, chest pain, fatigue and malaise, pneumonia, and bilateral chest CT infiltration. Soon COVID-19 spread around the world and turned into a pandemic. Now this disease affects many patients around the world. Patients with concomitant diseases have a high risk of COVID-19 infection, the infection is quite severe, leading to organ dysfunction, which is acute respiratory distress syndrome, acute kidney damage, septic shock, pneumonia and death. Currently, the coronavirus disease (COVID-19) is an imminent threat to global public health. Experts around the world are now actively searching for medicines that can stop the infection. Despite the fact that some modern therapeutic drugs have demonstrated quite high capabilities in the field of prevention or treatment of patients with COVID-19, various side effects have occurred during their use. Therefore, a comprehensive assessment of the safety profile of therapeutic agents against COVID-19 is highly relevant.
\end{abstract}

Keywords: COVID-19, therapeutic medicines, specific therapy, drug adaptive reuse.

\title{
Resumen
}

El nuevo coronavirus (COVID-19) se detectó por primera vez en la ciudad de Wuhan en China en diciembre de 2019. La mayoría de los pacientes infectados con COVID-19 tenían manifestaciones clínicas de tos seca, fiebre, dificultad para respirar, dolor en el pecho, fatiga y malestar, neumonía e infiltración bilateral de TC de tórax. Pronto, COVID-19 se extendió por todo el mundo y se convirtió en una pandemia. Ahora bien, esta enfermedad afecta a muchos pacientes en todo el mundo. Los pacientes con enfermedades concomitantes tienen un alto riesgo de infección por COVID-19, la infección es bastante grave y conduce a una disfunción orgánica, que es síndrome de dificultad respiratoria aguda, daño renal agudo, shock séptico, neumonía y muerte. Actualmente, la enfermedad por coronavirus (COVID-19) es una amenaza inminente para la salud pública mundial. Los expertos de todo el mundo están buscando activamente medicamentos que puedan detener la infección. A pesar de que algunos fármacos terapéuticos modernos han demostrado capacidades bastante elevadas en el campo de la prevención o el tratamiento de pacientes con COVID-19, se han producido varios efectos secundarios durante su uso. Por lo tanto, una evaluación integral del perfil de seguridad de los agentes terapéuticos frente al COVID-19 es muy relevante.

Palabras clave: COVID-19, medicamentos terapéuticos, terapia específica, reutilización adaptativa de fármacos.

\section{Introduction}

Coronaviruses are membranous, unsegmented, and single-stranded RNA viruses with a positive meaning. The starting point for the spread of this disease should be considered the end of December 2019, when new cases of pneumonia caused by this virus were first detected in the Chinese city of Wuhan. The most common clinical signs and symptoms in the first and subsequent patients were dry cough, fever, shortness of breath, and bilateral chest $\mathrm{CT}$ infiltration. The causative agent of the new coronavirus was first detected using swobs taken from these patients.

This new coronavirus was later named the severe acute respiratory syndrome coronavirus (SARS-CoV-2). Soon this disease was named (COVID-19), and its spread became pandemic.

Most patients infected with COVID-19 have an average age of 50 years, most often the virus affects men. Approximately $25 \%$ of infected patients with severe forms of the disease are treated in hospitals, while $10 \%$ of these patients require artificial lung ventilation.

Studies of European specialists in Italy showed that COVID-19 prevailed in men (59.8\% in men and $40.2 \%$ in women), the majority of patients (about 75\%) were over 50 years old, approximately $46 \%$ of all patients had a mild form of the disease, $25 \%$ showed a severe course of the disease, 
$5 \%$ were in a critical situation, and the remaining patients had minor symptoms, unspecified symptoms, or completely absent symptoms (Huang et al., 2020).

According to recently published studies, the most common clinical manifestations in patients with COVID-19 were fever in $83-98 \%$ of patients, dry cough in $76-82 \%$, and fatigue or myalgia in $11-44 \%$ of them. Other signs and symptoms reported include sore throat, headache, confusion, rhinorrhea, sneezing, ageusia, anosmia, chest pain, hypoxemia, pneumonia, hemoptysis, acute heart failure, neurological complications, and gastrointestinal symptoms such as nausea, vomiting, diarrhea, and abdominal pain.

Patients with concomitant diseases are very likely to develop severe infection, which is expressed through acute respiratory distress syndrome, acute kidney injury, septic shock, etc. A severe form of COVID-19 can lead to death due to severe alveolar damage and highly progressive respiratory failure.

CAVID-19 particles can be spread through the airway mucosa and through the fecal-oral route. The virus's nucleic acid was found in excrement samples and saliva. This virus can be transmitted from person to person, and this form of transmission can significantly accelerate the spread of this virus.

Studies have shown that COVID-19 can also be transmitted by an asymptomatic carrier with an incubation period of 1 to 19 days. To prevent the spread of this new virus, hands should be washed frequently, you should not touch your face with unwashed hands, regular disinfection of surfaces is required, social distancing from people with respiratory symptoms is necessary, and other precautions are taken.

Covid-19 diagnostics is also a special feature. According to published reports, in most patients with COVID-19, the absolute value of lymphocytes was reduced, indicating that this new coronavirus (COVID-19) acts more on lymphocytes, especially on T-lymphocytes, like the SARS coronavirus.

COVID-19 can cause a cytokine storm and activate immune responses, which can manifest in changes in the number of white blood cells and immune cells, especially lymphocytes. The clinical outcome of such events will be respiratory distress syndrome, septic shock, and finally, damage to the target organ. COVID-19 can also affect the liver, resulting in hypoproteinemia, increased aminotransferases, and prolonged prothrombin time. Hepatotoxicity can be explained by higher expression of angiotensin converting enzyme II (ACE2) in cholangiocytes, ACE2 can act as an input receptor for COVID-19. It is also assumed that this new virus can directly damage the intrahepatic bile ducts.

Pathological results of a liver biopsy of a patient with COVID-19 showed moderate microvesicular steatosis, as well as moderate portal and lobular activity, which may be the result of direct liver damage from SARS-CoV-2 or hepatotoxicity caused by antiviral drugs.

Almost all patients with COVID-19 were diagnosed with abnormal lung CT. The analysis of studies showed that on average, patients with the considered diagnosis had $10.5 \pm 6.4$ segments, and the number of affected lung segments was significantly higher in the group of patients with symptoms compared to asymptomatic carriers of the disease (Zang et al., 2020).

CT results showed that patients with COVID-19 may have both bilateral lung damage and peripheral or diffuse lung damage. The most common manifestations of chest CT were matte glass pattern, compaction, and fuzzy borders (Xia et al., 2020).

According to WHO-approved laboratory PCR tests for the diagnosis of COVID-19, the diagnosis is based on a nucleic acid amplification test (NAAT), such as rRT-PCR, which can detect COVID-19 RNA sequence. 


\section{Materials and Methods}

During the preparation of the work, we analyzed studies related to the use of non-specialized medicines for the treatment of a new coronavirus infection, as well as drugs developed directly for the treatment of COVID-19. The results of clinical studies related to the use of these medicines were also examined.

\section{Results}

As already noted, today medical specialists around the world are trying to find the most effective medicine against coronavirus infection. One of the directions in this area was the re-profiling of existing medicines.

The medicine repurposing approach speeds up the drug discovery process and attracts the attention of researchers in a wide variety of fields of science (Zhou et al., 2020). Due to the availability of in vitro and in vivo screening data, complete chemical optimization, toxicity studies, mass production, formulation development, and pharmacokinetic profiles approved by the FDA, the medicine development cycles for coronavirus infection are shortened in this case, since all these critical steps can be bypassed. In addition, there is no need for larger investments, and the safety of repurposed medicines has been proven in preclinical models. Consequently, the main advantages of drug of adaptive reuse are associated with the established safety of known candidate compounds, a significant reduction in the development time and costs associated with the promotion of a particular drug for clinical trials (Ruan et al., 2020).

Most of the repurposed drugs were discovered by accident. In addition to random observations, drug repurposing can be performed using several strategies, including binding assays, phenotypic screening methods, and so on. In (Ruan et al., 2020), a brief overview of various approaches to medicine repurposing was presented.

Table 1. Different approaches to re-purposing drugs for the treatment of COVID-19

\begin{tabular}{|c|c|}
\hline Name of approach & Description \\
\hline Binding assay & $\begin{array}{c}\text { Identification of binding interactions of ligands with anal- } \\
\text { ysis components }\end{array}$ \\
\hline Phenotypic screening & $\begin{array}{c}\text { Evaluates a large number of approved or developed medi- } \\
\text { cations in various predictive models } \\
\text { Evaluation of a number of connections in an array of in- } \\
\text { dependent models }\end{array}$ \\
\hline Targeted approach & $\begin{array}{c}\text { Identifying new indications on the basis of target proteins } \\
\text { of the medicine }\end{array}$ \\
\hline Scientific approach & $\begin{array}{c}\text { Combines known information about the medicine with } \\
\text { the prediction of unexplored biomarkers. }\end{array}$ \\
\hline Comparative approach & $\begin{array}{c}\text { Based on comparing the unique characteristics or "signa- } \\
\text { ture" of a medicine with the characteristics of another } \\
\text { medicine, disease, or clinical phenotype }\end{array}$ \\
\hline
\end{tabular}

Choosing the right approach is a crucial step in repurposing medicines. The possibilities for repurposing drugs are diverse, but much remains to be done to explore them.

Within the framework of the above approaches, various strategies for repurposing medicines are used to determine the effectiveness of known drugs in respiratory viral infectious diseases using both screening of collections of bioactive small molecules and computational methods. The main non-core drugs studied by various specialists for use against COVIND-19 are presented in table 2 .

Table 2. Repurposed drugs in clinical development against various indications caused by respiratory viruses

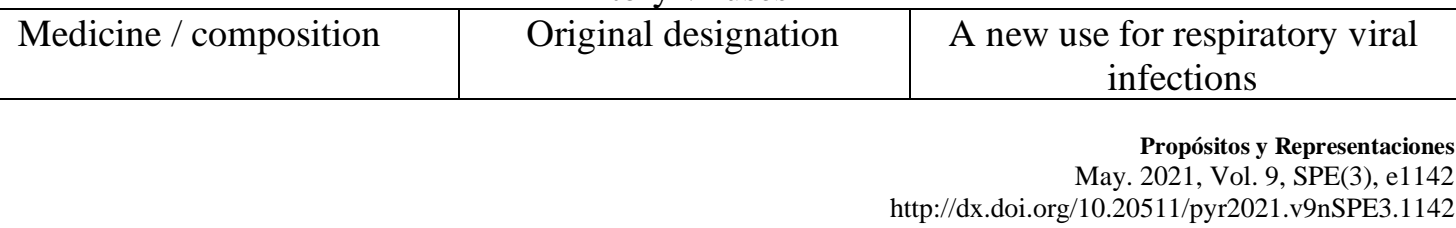




\begin{tabular}{|c|c|c|}
\hline Sarilumab & Rheumatoid arthritis & COVID-19 \\
\hline Favipiravir & Flu & COVID-19 \\
\hline Ramdevpir & $\begin{array}{c}\text { A wide range of antiviral } \\
\text { drugs }\end{array}$ & COVID-19 \\
\hline Danoprevir / ritonavir & Danoprevir for hepatitis C & Ritonavir for HIV \\
\hline Dexamethasone & $\begin{array}{c}\text { COVID-19-associated acute res- } \\
\text { piratory distress syndrome }\end{array}$ \\
\hline Ivermectin / doxycycline & Immunosuppressant & COVID-19 \\
\hline ASC09 / ritonavir & $\begin{array}{c}\text { Ivermectin for parasitic } \\
\text { infections }\end{array}$ & COVID-19 \\
\hline Hydroxychloroquine & $\begin{array}{c}\text { Doxycycline for bacterial } \\
\text { infections }\end{array}$ & COVID-19 \\
\hline Methylprednisolone & Ritonavir for HIV & COVID-19 \\
\hline Tocilizumab & Malaria & \\
\hline
\end{tabular}

If an antiviral medicine has the ability to affect a specific pathway used for virus replication and is active against other viruses, it may be useful against COVID-19 (Ragab et al., 2020).

Remdesivir, a broad-spectrum antiviral drug under investigation, has shown promising efficacy in the treatment of MERS and SARS. Several recent studies have reported the effectiveness of remdesivir in the treatment of COVID-19 (Ragab et al., 2020). Similarly, chloroquine (approved for the treatment of malaria) has shown potential for reuse against influenza (Ye et al., 2020), MERS (suppression of virus replication), SARS, and COVID-19 (Ye et al., 2020).

In addition, hydroxychloroquine (HCQ) has shown positive effects in the treatment of COVID-19, as reported in several recent studies (Ye et al., 2020). on March 28, 2020, the food and drug administration (FDA) issued an emergency use allowance (EUA) for the use of chloroquine phosphate and hydroxychloroquine sulfate for the treatment of COVID-19 (Xu et al., 2020). In addition, on May 1, 2020, the FDA granted permission for the use of remdesivir in emergency cases (EUA) for the treatment of COVID-19. However, June 15, 2020 The FDA has withdrawn EUA for emergency use of the oral formulations chloroquine phosphate and hydroxychloroquine sulfate based on current EUA analysis and new scientific data (Xu et al., 2020).

Researcher L. Heimfarthab and her co-authors also studied many classes of drugs to minimize the effects of COVID-19 (Heimfarth et al., 2020). They suggested that some of these drugs, such as chloroquine (CQ) and hydroxychloroquine (HCQ), had caused unnecessary insanity due to their indiscriminate use as preventive measures in a number of countries, including Brazil and the United States.

Although this is not the main goal of most drugs currently used to treat COVID-19, there is growing evidence that the "cytokine storm" can have a significant impact on the development of the disease, especially in patients in critical condition (Heimfarth et al., 2020). However, there is no information on how these drugs can help control important cytokines and promote patient recovery.

Some drugs that have been studied for their potential usefulness in COVID-19 have an antiinflammatory profile in other diseases and are being tested against hyperinflammation caused by SAR-COV-2 infection.

Knowledge of the molecular targets of drugs in SAR-COV-2 infection and their subsequent effects on immune responses can help pave the way for empirical approaches and trials at this stage. The above authors presented a classification of drugs proposed for the treatment of COVID-19 that can modulate the observed inflammatory process. The classification includes antiviral, anti-rheumatic, anti-inflammatory, antitumor and antiparasitic drugs (table 3). It was noted that all these classes of drugs have a beneficial effect on patients with COVID-19 (Heimfarth et al., 2020).

Table 3. Drugs used in the treatment of COVID-19 


\begin{tabular}{|c|c|c|c|c|}
\hline Class & $\begin{array}{l}\text { Drug, remedy, } \\
\text { medicine }\end{array}$ & Main class & $\begin{array}{l}\text { Main mechanism } \\
\text { of action }\end{array}$ & $\begin{array}{l}\text { The prevail- } \\
\text { ing COVID- } \\
19 \text { manage- } \\
\text { ment mech- } \\
\text { anism }\end{array}$ \\
\hline \multicolumn{5}{|c|}{ Antiviral drugs for the treatment of COVID-19 and affected cytokines } \\
\hline \multirow[t]{6}{*}{ Antiviral drugs } & Atazanavir & $\begin{array}{l}\text { Antiretroviral } \\
\text { drug }\end{array}$ & $\begin{array}{c}\text { Inhibitor of } \\
\text { CYP3A and } \\
\text { UGT1A1 }\end{array}$ & $\begin{array}{c}\text { It blocks the } \\
\text { main prote- } \\
\text { ase (Mpro) } \\
\text { SARS- } \\
\text { CoV-2. }\end{array}$ \\
\hline & $\begin{array}{l}\text { Favipiravir } \\
\text { (Avigan) }\end{array}$ & Antiviral drug & $\begin{array}{l}\text { Competitive in- } \\
\text { hibitor of RNA- } \\
\text { dependent RNA } \\
\text { polymerase }\end{array}$ & $\begin{array}{l}\text { It prevents } \\
\text { virus } \\
\text { replication }\end{array}$ \\
\hline & $\begin{array}{l}\text { IFN- } \alpha 2 \mathrm{~b} \\
\text { (interferon) }\end{array}$ & $\begin{array}{l}\text { Antiviral drug } \\
\text { Immunomodula- } \\
\text { tory drug }\end{array}$ & $\begin{array}{l}\text { Formation of an } \\
\text { adaptive immune } \\
\text { response. } \\
\text { Suppression of } \\
\text { DNA replication. }\end{array}$ & $\begin{array}{c}\text { It sup- } \\
\text { presses } \\
\text { SARS-CoV } \\
\text { and MERS- } \\
\text { CoV repli- } \\
\text { cation. }\end{array}$ \\
\hline & $\begin{array}{l}\text { Lopinavir- } \\
\text { ritonavir }\end{array}$ & Antiviral drug & $\begin{array}{l}\text { Proteinase inhibi- } \\
\text { tor, proteinase in- } \\
\text { hibitor, antiretro- } \\
\text { viral proteinase } \\
\text { inhibitor }\end{array}$ & $\begin{array}{c}\text { It sup- } \\
\text { presses } \\
\text { CYP3A- } \\
\text { mediated } \\
\text { LPV metab- } \\
\text { olism, in- } \\
\text { hibits 3CL } \\
\text { pro due to } \\
\text { SARS-CoV, } \\
\text { affecting vi- } \\
\text { rus replica- } \\
\text { tion and } \\
\text { maturation; } \\
\text { Ritonavir } \\
\text { inhibits the } \\
\text { CYP3A me- } \\
\text { tabolism of } \\
\text { lopinavir, } \\
\text { increasing } \\
\text { its plasma } \\
\text { concentra- } \\
\text { tion } \\
\text { It is a prote- } \\
\text { ase inhibitor }\end{array}$ \\
\hline & Remdesivir & Antiviral drug & $\begin{array}{l}\text { Inhibitor RNA- } \\
\text { polymerase } \\
\text { A nucleoside ana- } \\
\text { logue }\end{array}$ & $\begin{array}{l}\text { Inhibitor } \\
\text { RNA- } \\
\text { polymerase }\end{array}$ \\
\hline & Ribavirin & Antiviral drug & $\begin{array}{l}\text { Stops the synthe- } \\
\text { sis of viral RNA }\end{array}$ & $\begin{array}{l}\text { An ana- } \\
\text { logue of nu- } \\
\text { cleosides } \\
\text { that inter- } \\
\text { feres with } \\
\text { the replica- } \\
\text { tion of RNA }\end{array}$ \\
\hline
\end{tabular}




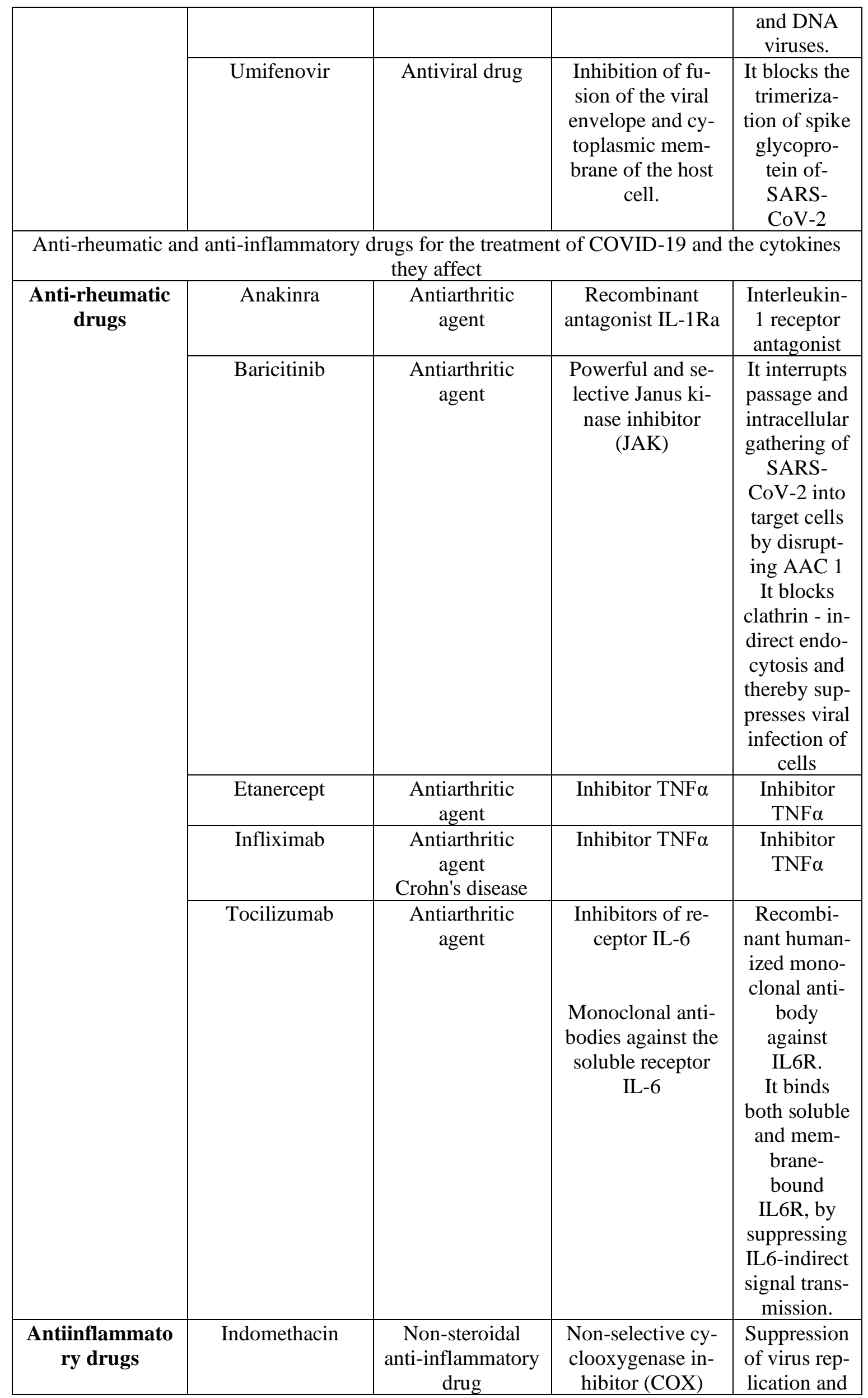




\begin{tabular}{|c|c|c|c|c|}
\hline & & & & $\begin{array}{c}\text { production } \\
\text { of infectious } \\
\text { virus parti- } \\
\text { cles }\end{array}$ \\
\hline & Thalidomide & Phthalimides & $\begin{array}{l}\text { Immunomodula- } \\
\text { tory, anti-inflam- } \\
\text { matory and anti- } \\
\text { angiogenic medi- } \\
\text { cine }\end{array}$ & $\begin{array}{l}\text { An im- } \\
\text { munomodu- } \\
\text { latory and } \\
\text { anti-inflam- } \\
\text { matory } \\
\text { medicine }\end{array}$ \\
\hline & Corticosteroids & $\begin{array}{c}\text { Non-steroidal } \\
\text { anti-inflammatory } \\
\text { drug }\end{array}$ & $\begin{array}{c}\text { Suppression of } \\
\text { multiple inflam- } \\
\text { matory genes by } \\
\text { binding } \\
\text { glucocorticoids } \\
\text { with the involve- } \\
\text { ment } \\
\text { of histone } \\
\text { deacetylase } 2 \text { for } \\
\text { the activated tran- } \\
\text { scription complex. }\end{array}$ & $\begin{array}{l}\text { It sup- } \\
\text { presses the } \\
\text { transcrip- } \\
\text { tion factor } \\
\text { NFkB. }\end{array}$ \\
\hline \multicolumn{5}{|c|}{ ACEi and ARB drugs for the treatment of COVIND-19 and the cytokines they affect } \\
\hline ACEi & Enalapril & ACEi & $\begin{array}{l}\text { Angiotensin- } \\
\text { converting } \\
\text { enzyme inhibitors }\end{array}$ & $\begin{array}{l}\text { It reduces } \\
\text { the interac- } \\
\text { tion be- } \\
\text { tween the } \\
\text { viral protein } \\
\text { and ACE 2, } \\
\text { affecting the } \\
\text { internaliza- } \\
\text { tion of the } \\
\text { virus. }\end{array}$ \\
\hline \multirow[t]{2}{*}{ ARB } & Losartan & ARB & Antagonist $\mathrm{AT}_{1} \mathrm{R}$ & $\begin{array}{l}\text { It reduces } \\
\text { the interac- } \\
\text { tion be- } \\
\text { tween the } \\
\text { viral protein } \\
\text { and ACE2 }\end{array}$ \\
\hline & Telmisartan & ARB & Antagonist $\mathrm{AT}_{1} \mathrm{R}$ & $\begin{array}{l}\text { It reduces } \\
\text { the interac- } \\
\text { tion be- } \\
\text { tween the } \\
\text { viral protein } \\
\text { and ACE2 }\end{array}$ \\
\hline \multicolumn{5}{|c|}{$\begin{array}{c}\text { Anticancer, antibiotic, and antiparasitic drugs for the treatment of COVID-19 and the cytokines } \\
\text { they affect }\end{array}$} \\
\hline $\begin{array}{l}\text { Anticancer } \\
\quad \text { drugs }\end{array}$ & Ibrutinib & Anticancer drug & $\begin{array}{l}\text { Covalent } \\
\text { inhibitors of TCI }\end{array}$ & $\begin{array}{l}\text { It prevents } \\
\text { B-cell acti- } \\
\text { vation and } \\
\text { transmis- } \\
\text { sion of B- } \\
\text { cell-indirect } \\
\text { signals } \\
\text { (suggestion) }\end{array}$ \\
\hline
\end{tabular}




\begin{tabular}{|c|c|c|c|c|}
\hline & Ruxolitinib & $\begin{array}{c}\text { Antitumor and } \\
\text { immunomodulato } \\
\text { ry effects }\end{array}$ & $\begin{array}{l}\text { Janus kinase } \\
\text { inhibitors }\end{array}$ & $\begin{array}{c}\text { Janus kinase } \\
\text { inhibitors }\end{array}$ \\
\hline Antibiotic & Azithromycin & Antibiotic & $\begin{array}{l}\text { It binds with the } \\
50 \mathrm{~S} \text { subunit of the } \\
\text { ribosome, affect- } \\
\text { ing bacterial pro- } \\
\text { tein synthesis. }\end{array}$ & \\
\hline \multirow[t]{4}{*}{$\begin{array}{c}\text { Antiparasitic } \\
\text { drugs }\end{array}$} & Chloroquine & Antimalarial drug & $\begin{array}{l}\text { Immunosuppressi } \\
\text { on }\end{array}$ & $\begin{array}{l}\text { It changes } \\
\text { the pH in } \\
\text { lysosomes. } \\
\text { It prevents } \\
\text { viruses from } \\
\text { merging and } \\
\text { replicating. } \\
\text { Spike (S) - } \\
\text { protein } \\
\text { blockers of } \\
\text { angiotensin- } \\
\text { converting } \\
\text { enzyme 2 } \\
\text { (ACE2) }\end{array}$ \\
\hline & $\begin{array}{l}\text { Hydroxychloroqui } \\
\text { ne }\end{array}$ & $\begin{array}{l}\text { Anti-malarial } \\
\text { drugs anti-rheu- } \\
\text { matic drugs } \\
\text { that modify the } \\
\text { disease (disease- } \\
\text { modifying anti- } \\
\text { rheumatic drug) }\end{array}$ & $\begin{array}{l}\text { Immunosuppressi } \\
\text { on }\end{array}$ & $\begin{array}{l}\text { Inhibition of } \\
\text { the SARS- } \\
\text { CoV cell re- } \\
\text { ceptor } \\
\text { (ACE 2), vi- } \\
\text { rus mem- } \\
\text { brane fusion } \\
\text { in the host, } \\
\text { nucleic acid } \\
\text { replication, } \\
\text { new virus } \\
\text { transport, } \\
\text { virus re- } \\
\text { lease. }\end{array}$ \\
\hline & Ivermectin & $\begin{array}{l}\text { Broad-spectrum } \\
\text { antiparasitic agent } \\
\text { Antiviral medi- } \\
\text { cine ( in vitro ) }\end{array}$ & $\begin{array}{c}\text { Inhibitory activity } \\
\text { of nuclear } \\
\text { transport }\end{array}$ & $\begin{array}{l}\text { Inhibitory } \\
\text { activity of } \\
\text { nuclear } \\
\text { transport }\end{array}$ \\
\hline & $\begin{array}{l}\text { Nitazoxanide } \\
\text { (anitta) }\end{array}$ & $\begin{array}{l}\text { Antiprotozoal } \\
\text { drug }\end{array}$ & $\begin{array}{l}\text { It increases the } \\
\text { production of in- } \\
\text { terferon alpha and } \\
\text { beta interferon }\end{array}$ & $\begin{array}{l}\text { It affects the } \\
\text { synthesis of } \\
\text { the viral ge- } \\
\text { nome } \\
\text { It prevents } \\
\text { virus entry } \\
\text { and pre- } \\
\text { vents N-gly- } \\
\text { cosylation }\end{array}$ \\
\hline Others & Colchicine & $\begin{array}{l}\text { Antipodagric } \\
\text { medicine }\end{array}$ & $\begin{array}{c}\text { Microtubule in- } \\
\text { hibitor } \\
\text { (colchicine blocks } \\
\text { microtubule } \\
\text { polymerization) }\end{array}$ & $\begin{array}{l}\text { A non-se- } \\
\text { lective in- } \\
\text { hibitor of } \\
\text { NLRP3 in- } \\
\text { flam- } \\
\text { masome }\end{array}$ \\
\hline
\end{tabular}




\begin{tabular}{|c|c|c|c|c|}
\hline & & & $\begin{array}{c}\text { Anti- } \\
\text { inflammator } \\
\text { y effect }\end{array}$ \\
\hline
\end{tabular}

Research by medical specialists from China on the choice and effectiveness of medicines for the treatment of patients with a new coronavirus infection is also interesting. In China, the practice of fighting SARS-CoV-2 over the past four months has fully confirmed that traditional Chinese medicine plays an important role in the prevention and treatment of COVID-19 before the successful development of specific medicines and vaccines. Combined methods of treatment of traditional Chinese medicine and chemical preparations increased clinical effectiveness, reduced the length of hospital stay, and reduced the critical mortality rate (Pan et al., 2020). Therefore, these drugs, including recipes for Chinese herbal compounds, injectable drugs, and natural active ingredients with specific effects for the prevention and treatment of COVID-19, should be generalized and distributed. Prescriptions for Chinese herbal compounds and injectable medications that have tried to prevent and treat COVID-19 in China are listed in table 4 (Pan et al., 2020).

Table 4. Traditional Chinese medicine medications that can potentially be used for the prevention and treatment of COVID-19

\begin{tabular}{|c|c|c|c|c|}
\hline $\begin{array}{l}\text { Traditional } \\
\text { Chinese } \\
\text { medicines }\end{array}$ & Compositions & Indications & Adverse reaction & $\begin{array}{l}\text { General usage (for refer- } \\
\text { ence only) }\end{array}$ \\
\hline $\begin{array}{l}\text { Huoxiang- } \\
\text { zhengqi } \\
\text { prepara- } \\
\text { tions (cap- } \\
\text { sule, pill, } \\
\text { water, liq- } \\
\text { uid for } \\
\text { oral ad- } \\
\text { ministra- } \\
\text { tion) }\end{array}$ & $\begin{array}{l}13 \text { types of herbs: Po- } \\
\text { gostemonis } \\
\text { Herba, Perillae Fo- } \\
\text { lium, Angelicae da- } \\
\text { huricae Radix , At- } \\
\text { ractylodis macroceph- } \\
\text { alae Rhizoma, Citri } \\
\text { reticulatae Pericar- } \\
\text { pium, Pinelliae Rhi- } \\
\text { zoma Praepara- } \\
\text { tum, Magnoliae of- } \\
\text { ficinalis Cor- } \\
\text { tex , Poria and others. }\end{array}$ & $\begin{array}{l}\text { Migraines, flu, } \\
\text { acute upper res- } \\
\text { piratory tract in- } \\
\text { fection, heat } \\
\text { stroke, func- } \\
\text { tional dyspepsia, } \\
\text { etc. }\end{array}$ & $\begin{array}{l}\text { Some people may } \\
\text { have skin damage, } \\
\text { redness, palpitations, } \\
\text { dizziness, rash, itch- } \\
\text { ing, disulfiram-like } \\
\text { reaction in combina- } \\
\text { tion with cephalo- } \\
\text { sporins, etc. }\end{array}$ & $\begin{array}{l}\text { An oral solution of wa- } \\
\text { ter or HuoxiangZhengqi } \\
\text { solution is } 5-10 \text { ml once } \\
\text { - twice a day. Tablets of } \\
2.5-5 \text { g: once- } 2 \text { times a } \\
\text { day. Capsules are } 4 \text { cap- } \\
\text { sules once or twice a } \\
\text { day. The diet should be } \\
\text { light while taking } \\
\text { medication }\end{array}$ \\
\hline $\begin{array}{c}\text { Jinhua } \\
\text { Tsingan } \\
\text { Pellets }\end{array}$ & $\begin{array}{l}\text { Lonicerae japonicae } \\
\text { Flos , Fritillariae } \\
\text { thunbergii Bul- } \\
\text { bus , Scutellariae Ra- } \\
\text { dix , Arctii Fruc- } \\
\text { tus , Artemisiae an- } \\
\text { nuae Herba and oth- } \\
\text { ers. }\end{array}$ & $\begin{array}{l}\text { Various flu : } \\
\text { flu a (H1N1) }\end{array}$ & Uncertain & $\begin{array}{l}\text { Take one sachet with } \\
\text { boiled water twice a day } \\
\text { for } 3-5 \text { days or as pre- } \\
\text { scribed by your doctor. } \\
\text { Avoid spicy, cold, and } \\
\text { fatty food }\end{array}$ \\
\hline $\begin{array}{c}\text { Lianhua } \\
\text { Qingwen } \\
\text { Capsule } \\
\text { (granules) }\end{array}$ & $\begin{array}{c}13 \text { types of } \\
\text { herbs: Forsythiae } \\
\text { Fructus , Lonicerae } \\
\text { japonicae } \\
\text { Flos, Ephedrae } \\
\text { Herba, Armeniacae } \\
\text { semen Ama- } \\
\text { rum , Gypsum Fibro- } \\
\text { sum, Isatidis Ra- } \\
\text { dix , Dryopteridis } \\
\text { crassirhizomatis Rhi- } \\
\text { zoma, Houttuyniae } \\
\text { Herba, Pogostemonis } \\
\text { Herba and others. }\end{array}$ & Flu & $\begin{array}{l}\text { It usually occurs af- } \\
\text { ter the first dose of } \\
\text { medication, such as } \\
\text { nausea, vomiting, } \\
\text { bloating, diarrhea, } \\
\text { rash, itching, etc. }\end{array}$ & $\begin{array}{l}\text { Oral administration of } 4 \\
\text { capsules or one granule } \\
\text { at a time, three times a } \\
\text { day. } 7-10 \text { days as a } \\
\text { course for the mild and } \\
\text { common form of } \\
\text { COVID-19 }\end{array}$ \\
\hline
\end{tabular}




\begin{tabular}{|c|c|c|c|c|}
\hline $\begin{array}{l}\text { Shufeng } \\
\text { Jiedu } \\
\text { Capsule } \\
\text { (granules) }\end{array}$ & $\begin{array}{c}\text { Polygoni cuspidate } \\
\text { Rhizoma et } \\
\text { Radix , Forsythiae } \\
\text { Fructus , Isatidis } \\
\text { Radix , Bupleuri } \\
\text { Radix , Patriniae } \\
\text { Herba , Verbenae } \\
\text { Herba , Phragmitis } \\
\text { Rhizoma, Glycyrrhiz } \\
\text { ae Radix et Rhizoma }\end{array}$ & $\begin{array}{l}\text { Acute upper res- } \\
\text { piratory tract in- } \\
\text { fection }\end{array}$ & $\begin{array}{l}\text { Sometimes nausea, } \\
\text { rash, dizziness, head- } \\
\text { ache, high blood } \\
\text { pressure, etc. }\end{array}$ & $\begin{array}{l}\text { Oral administration of } 4 \\
\text { tablets three times a day. }\end{array}$ \\
\hline $\begin{array}{c}\text { Tablets } \\
\text { Fangfeng } \\
\text { Tongshen } \\
\text { g } \\
\text { (granules) }\end{array}$ & $\begin{array}{c}17 \text { types of } \\
\text { herbs: Saposhnikov- } \\
\text { iae Radix , Schi- } \\
\text { zonepetae } \\
\text { Spica, Menthae hap- } \\
\text { localycis } \\
\text { Herba, Ephedrae } \\
\text { Herba, Rhei Radix et } \\
\text { Rhizoma, Natrii Sul- } \\
\text { fas, Gardeniae Fruc- } \\
\text { tus and others }\end{array}$ & $\begin{array}{l}\text { Urticaria, } \\
\text { eczema, } \\
\text { constipation }\end{array}$ & $\begin{array}{l}\text { Sometimes an } \\
\text { allergic rash }\end{array}$ & $\begin{array}{l}\text { Oral administration, one } \\
\text { tablet, twice a day. }\end{array}$ \\
\hline $\begin{array}{c}\text { Granules } \\
\text { Toujie } \\
\text { Quwen } \\
\text { (from } \\
\text { pneumo- } \\
\text { nia \#1 on } \\
\text { prescrip- } \\
\text { tion) }\end{array}$ & $\begin{array}{l}16 \text { types of } \\
\text { herbs: Scutellariae } \\
\text { Radix, Forsythiae } \\
\text { Fructus, Lonicerae } \\
\text { japonicae Flos, Isa- } \\
\text { tidis Foliu and others }\end{array}$ & Antivirus & Uncertain & $\begin{array}{l}\text { Oral administration, } 2 \\
\text { sachets at a time, each } \\
\text { sachet } 11 \mathrm{~g} \text {, twice a day. }\end{array}$ \\
\hline $\begin{array}{l}\text { Tsingfei } \\
\text { Paidu } \\
\text { Decoction }\end{array}$ & $\begin{array}{c}21 \text { types of } \\
\text { herbs: Ephedrae } \\
\text { Herba, Armeniacae } \\
\text { semen Ama- } \\
\text { rum , Gypsum Fibro- } \\
\text { sum, Asari Radix et } \\
\text { Rhizoma, Bupleuri } \\
\text { Radix , Scutellariae } \\
\text { Radix , Citri reticula- } \\
\text { tae Pericarpium and } \\
\text { others }\end{array}$ & $\begin{array}{l}\text { Measles, } \\
\text { pneumonia }\end{array}$ & $\begin{array}{l}\text { It may occur after in- } \\
\text { appropriate medica- } \\
\text { tion, such as exces- } \\
\text { sive sweating, epi- } \\
\text { gastric discomfort, } \\
\text { diarrhea, and in- } \\
\text { creased arterial pres- } \\
\text { sure. }\end{array}$ & $\begin{array}{l}\text { One dose a day, once in } \\
\text { the morning and even- } \\
\text { ing (in } 40 \text { minutes after } \\
\text { meals), take with warm } \\
\text { water, three times by a } \\
\text { course. If possible, add } \\
\text { half a cup of rice soup } \\
\text { after each serving. }\end{array}$ \\
\hline $\begin{array}{l}\text { Huashi } \\
\text { Baidu } \\
\text { Recipe }\end{array}$ & $\begin{array}{c}14 \text { types of } \\
\text { herbs: Ephedrae } \\
\text { Herba, Pogostemonis } \\
\text { Herba, Gypsum Fi- } \\
\text { brosum , Armeniacae } \\
\text { semen Amarum , Pi- } \\
\text { nelliae Rhizoma Prae- } \\
\text { paratum , Rhei Radix } \\
\text { et Rhizoma , Glycyr- } \\
\text { rhizae Radix et Rhi- } \\
\text { zoma and others. }\end{array}$ & Pneumonia & Uncertain & $\begin{array}{l}\text { 1-2 doses per day, de- } \\
\text { coction, 100-200 ml } \\
\text { each time, 2-4 times a } \\
\text { day, oral or nasal feed- } \\
\text { ing }\end{array}$ \\
\hline $\begin{array}{l}\text { Decoction } \\
\text { of Suanfei } \\
\text { Baidu }\end{array}$ & $\begin{array}{c}13 \text { types of } \\
\text { herbs: Ephedrae } \\
\text { Herba, Armeniacae } \\
\text { semen Ama- } \\
\text { rum , Gypsum Fibro- } \\
\text { sum , Pogostemonis }\end{array}$ & Pneumonia & Uncertain & $\begin{array}{l}\text { One dose per day, } 400 \\
\text { ml decoction, take } 200 \\
\text { ml in the morning and } \\
\text { evening, respectively. }\end{array}$ \\
\hline
\end{tabular}




\begin{tabular}{|c|c|c|c|c|}
\hline & $\begin{array}{l}\text { Herba, Artemisiae } \\
\text { annuae } \\
\text { Herba, Glycyrrhizae } \\
\text { Radix et Rhi- } \\
\text { zoma and others }\end{array}$ & & & \\
\hline $\begin{array}{l}\text { Ciyanping } \\
\text { for } \\
\text { injections }\end{array}$ & $\begin{array}{l}\text { Andrographolide } \\
\text { ether sulfonate }\end{array}$ & $\begin{array}{l}\text { Acute viral in- } \\
\text { fection of the } \\
\text { upper respira- } \\
\text { tory tract, viral } \\
\text { bacterial pneu- } \\
\text { monia, influ- } \\
\text { enza, acute and } \\
\text { chronic bronchi- } \\
\text { tis }\end{array}$ & $\begin{array}{l}\text { Digestive symptoms } \\
\text { such as nausea and } \\
\text { vomiting. }\end{array}$ & $\begin{array}{c}\text { Viral infection or com- } \\
\text { bined mild bacterial in- } \\
\text { fection: } 0.9 \% \text { sodium } \\
\text { chloride injection } 250 \\
\text { ml + Ciyanping injec- } \\
\text { tion } 100 \text { mg } 2 \text { times a } \\
\text { day }\end{array}$ \\
\hline $\begin{array}{l}\text { Xuebijing } \\
\text { injection }\end{array}$ & $\begin{array}{l}\text { Carthami Flos, Paeo- } \\
\text { niae Radix Ru- } \\
\text { bra, Chuanxiong } \\
\text { Rhizoma, Salviae } \\
\text { miltiorrhizae Radix et } \\
\text { Rhizoma and Angeli- } \\
\text { cae sinensis Radix }\end{array}$ & Lung infection & $\begin{array}{l}\text { Chest tightness, rash, } \\
\text { anaphylactic shock, } \\
\text { fever, abdominal } \\
\text { pain, nausea, vomit- } \\
\text { ing, drop in blood } \\
\text { pressure, etc. }\end{array}$ & $\begin{array}{l}\text { Systemic inflammatory } \\
\text { reaction or polyfunc- } \\
\text { tional organ failure: } \\
0.9 \% \text { sodium chloride } \\
\text { injection } 250 \mathrm{ml}+ \\
\text { xuebijing injection } 100 \\
\text { ml - } 2 \text { times a day. }\end{array}$ \\
\hline $\begin{array}{l}\text { Shen fu } \\
\text { injection }\end{array}$ & $\begin{array}{c}\text { Radix et Rhizoma ru- } \\
\text { bra ginseng and aco- } \\
\text { niti lateralis radix } \\
\text { praeparata extract } \\
\end{array}$ & $\begin{array}{l}\text { Septic, hemor- } \\
\text { rhagic and dehy- } \\
\text { drating shock }\end{array}$ & Uncertain & $\begin{array}{c}\text { Shock: injection of } 0.9 \% \\
\text { sodium chloride }-250 \\
\text { ml + injection of } 100 \mathrm{ml} \\
\text { Shenfu } 2 \text { times a day. }\end{array}$ \\
\hline $\begin{array}{l}\text { Shengmai } \\
\text { injection }\end{array}$ & $\begin{array}{l}\text { Ginseng Radix et } \\
\text { Rhizoma ru- } \\
\text { bra, Ophiopogonis } \\
\text { Radix and Schisan- } \\
\text { drae chinensis Fruc- } \\
\text { tus }\end{array}$ & $\begin{array}{l}\text { Septic shock, } \\
\text { coronary heart } \\
\text { disease, angina, } \\
\text { epidemic hem- } \\
\text { orrhagic fever, } \\
\text { arrhythmia }\end{array}$ & $\begin{array}{l}\text { Allergic rash, back } \\
\text { pain }\end{array}$ & $\begin{array}{l}\text { Immunosuppression: } \\
\text { glucose injection } 250 \mathrm{ml} \\
\text { + Shengmai injection } \\
20-60 \mathrm{ml} 2 \text { times a day. }\end{array}$ \\
\hline $\begin{array}{l}\text { Re-injec- } \\
\text { tion }\end{array}$ & $\begin{array}{l}\text { Artemisiae annuae } \\
\text { Herba, Lonicerae ja- } \\
\text { ponicae Flos and Gar- } \\
\text { deniae Fructus }\end{array}$ & $\begin{array}{l}\text { Upper } \\
\text { respiratory tract } \\
\text { infection }\end{array}$ & $\begin{array}{l}\text { Individual patients } \\
\text { may experience diz- } \\
\text { ziness, chest tight- } \\
\text { ness, dry mouth, di- } \\
\text { arrhea, nausea, and } \\
\text { vomiting. Occasional } \\
\text { allergic reactions, } \\
\text { such as redness, itch- } \\
\text { ing, or a rash all over } \\
\text { the body. }\end{array}$ & $\begin{array}{c}\text { Viral infection or com- } \\
\text { bined mild bacterial in- } \\
\text { fection: injection of } \\
0.9 \% \text { sodium chloride } \\
250 \mathrm{ml}+\text { repeated injec- } \\
\text { tion of } 20 \mathrm{ml} 2 \text { times a } \\
\text { day }\end{array}$ \\
\hline $\begin{array}{l}\text { Tanrecin } \\
\text { for } \\
\text { injections }\end{array}$ & $\begin{array}{c}\text { Scutellariae Ra- } \\
\text { dix , Pulvis fetis } \\
\text { Ursi, Goat horn, Lo- } \\
\text { nicerae japonicae } \\
\text { Flos and Forsythiae } \\
\text { Fructus }\end{array}$ & $\begin{array}{l}\text { Acute bronchi- } \\
\text { tis, acute pneu- } \\
\text { monia (early } \\
\text { stage) }\end{array}$ & $\begin{array}{l}\text { Allergies, anaphylac- } \\
\text { tic shock, dizziness, } \\
\text { nausea, vomiting, } \\
\text { itching, rash, high fe- } \\
\text { ver, heart and kidney } \\
\text { function disorders, } \\
\text { etc. }\end{array}$ & $\begin{array}{l}\text { Viral infection or com- } \\
\text { bined mild bacterial in- } \\
\text { fection: } 0.9 \% \text { sodium } \\
\text { chloride solution for in- } \\
\text { jection } 250 \mathrm{ml}+ \\
\text { Tanrecin injection } 40 \mathrm{ml} \\
2 \text { times a day }\end{array}$ \\
\hline $\begin{array}{l}\text { Xingnaoji } \\
\text { ng injec- } \\
\text { tion }\end{array}$ & $\begin{array}{l}\text { Moschus, Gardeniae } \\
\text { Fructus, Curcumae } \\
\text { Radix and Borneolum } \\
\text { Syntheticum }\end{array}$ & $\begin{array}{l}\text { Epidemic en- } \\
\text { cephalitis B, he- } \\
\text { patic coma }\end{array}$ & $\begin{array}{l}\text { Accidental allergic } \\
\text { reactions, including } \\
\text { itching, rash, and fe- } \\
\text { ver. Sometimes there } \\
\text { are adverse symp- } \\
\text { toms such as tight- } \\
\text { ness in the chest, } \\
\text { belching, rapid }\end{array}$ & $\begin{array}{l}\text { High fever with im- } \\
\text { paired consciousness: } \\
0.9 \% \text { sodium chloride } \\
\text { solution for injection } \\
250 \mathrm{ml}+\text { injection Xing- } \\
\text { naojing } 20 \mathrm{ml} 2 \text { times a } \\
\text { day. }\end{array}$ \\
\hline
\end{tabular}




\begin{tabular}{|c|c|c|c|c|}
\hline & & & $\begin{array}{c}\text { breathing and rapid } \\
\text { heartbeat. }\end{array}$ & \\
\hline $\begin{array}{l}\text { Shenmai } \\
\text { injection }\end{array}$ & $\begin{array}{c}\text { Ginseng Radix et } \\
\text { Rhizoma ru- } \\
\text { bra and Ophiopogonis } \\
\text { Radix }\end{array}$ & $\begin{array}{c}\text { Shock, coronary } \\
\text { heart disease, vi- } \\
\text { ral myocarditis, } \\
\text { chronic tubercu- } \\
\text { losis disease, } \\
\text { granulocytope- } \\
\text { nia. }\end{array}$ & $\begin{array}{l}\text { Occasional allergic } \\
\text { reactions, such as } \\
\text { palpitations, short- } \\
\text { ness of breath, tight- } \\
\text { ness in the chest, red- } \\
\text { ness of the face, etc. } \\
\text { Sometimes } \\
\text { anaphylactic shock, } \\
\text { shortness of breath, } \\
\text { and heart failure. }\end{array}$ & $\begin{array}{l}\text { Immunosuppression: } \\
250 \mathrm{ml} \text { glucose injection } \\
+100 \mathrm{ml} \text { Shenmai injec- } \\
\text { tion twice a day }\end{array}$ \\
\hline
\end{tabular}

However, the authors point out that the clinical use of the above-mentioned medicines of traditional Chinese medicine requires special attention to contraindications to medicines (Pan et al., 2020).

\section{Discussion}

Next, we think, it necessary to consider the effectiveness and results of clinical trials of some of the drugs presented above. 1. Lopinavir / ritonavir. Initially, this drug was mainly used for the treatment of human immunodeficiency virus (HIV) infection in adults and children over 2 years of age. In vitro studies have shown that lopinavir and ritonavir can reduce SARS-CoV and MERS-CoV levels (Li et al., 2020). Based on the results of significant clinical benefits of lopinavir and ritonavir in patients with SARS-CoV infection, scientists have suggested that this drug may be effective in patients with SARS-CoV-2 infection (Li et al., 2020). The team from Zhongshan University built a structural model of two new coronavirus proteases-coronavirus endopeptidase C30 and papain-like protein using homology modeling and docked lopinavir / ritonavir with protease models, respectively. The results showed that lopinavir and ritonavir are more easily combined with coronavirus endopeptidase C30 compared to pa-pain-like enzymes that exhibit excellent effects against SARSCoV-2 (Coperchini et al., 2020). However, after using lopinavir / ritonavir tablets, 40 patients diagnosed with COVID-19 in 29 cases experienced adverse reactions associated with lopinavir / ritonavir, such as increased triglyceride levels, nausea, and diarrhea (Russell et al., 2020). Therefore, larger clinical trials of this drug should focus on its safety.

2. Ribavirin. It is a broad-spectrum antiviral drug that can be phosphorylated in red blood cells to form ribavirin monophosphate, diphosphate, and triphosphate. Ribavirin monophosphate is a strong inhibitor of inosinemonophosphatedehydrogenase, which can inhibit the synthesis of guanylatephosphate in cells, reduce the level of guanylate triphosphate in cells, and block the synthesis of viral nucleic acids. Ribavirin triphosphate inhibits influenza virus RNA-polymerase, thereby preventing virus replication (Zhang et al., 2020). Ribavirin has been shown to inhibit SARS$\mathrm{CoV}$ replication in five different cell types obtained from animals or humans in therapeutically achievable concentrations (Zhang et al., 2020). However, when using ribavirin, some side effects should be noted. For example, $61 \%$ of patients developed hemolytic anemia, 58\% hypocalcemia, and $46 \%$ hypomagnesemia in 110 SARS patients treated with ribavirin [14]. Taking into account the effectiveness of ribavirin in the treatment of diseases caused by SARS-CoV and MERS-CoV, it is expected to be an effective drug for the treatment of COVID-19. However, the effectiveness of ribavirin for the treatment of COVID-19 is still controversial, which are needed for further confirmation in clinical trials.

3. Chloroquine. Chloroquine is an anti-malarial and anti-inflammatory agent that has been widely used in the treatment of malaria and rheumatoid arthritis for more than 70 years. The antimalarial effect of chloroquine can interfere with replication and transcription of Plasmodium schizonta DNA or interfere with its endocytosis, which leads to the death of the parasite due to amino acid deficiency. Chloroquine also has an immunomodulatory activity that can synergistically enhance antiviral effects (McGonagle et al., 2020). Several consecutive clinical trials have now been announced. The results of an open non-randomized clinical study showed that hydroxychloroquine 
is significantly associated with a decrease or disappearance of the viral load in patients with COVID19 (Ulhaq, 2020). Similarly, another randomized clinical trial also confirmed the effectiveness of hydroxychloroquine against COVID-19, which is shown to reduce the recovery time of body temperature and the time of remission from cough in patients with COVID-19 (Ulhaq, 2020).

Preliminary data from a multicenter prospective observational study showed that the average time to undetectable viral RNA was shorter for chloroquine than for non-chloroquine, and no serious adverse reactions were observed in the chloroquine group (Levi et al., 2020). In contrast, the results of some clinical studies have shown negative results of treatment WITH covid-19 with chloroquine or hydroxychloroquine. For example, an open randomized controlled trial showed that hydroxychloroquine did not lead to a higher probability of negative conversion than applying a single standard of treatment in patients with mild to moderate COVID-19, and side effects, especially diarrhea, were higher after taking hydroxychloroquine (Zhang et al., 2020).

4. Arbidol. Arbidol inhibits the fusion between the viral envelope and the cell membrane of target cells, thereby preventing the virus from entering target cells (Snijder et al., 2006). Arbidol is often used to counter flu viruses in Russia and China, which is not yet approved for sale in other countries. In vitro and in vivo studies have shown that Arbidol has antiviral activity against influenza virus, RSV, rhinovirus, Coxsackie virus, Coxsackie B5 virus, and adenovirus (Snijder et al., 2006).

Previous research has shown that Arbidol can inhibit RNA viruses and filoviruses such as SARS-CoV and MERS-CoV. Chinese scientists have found that Arbidol can effectively suppress the pathological effects of SARS-CoV-2 at a concentration of $10 \sim 30 \mu \mathrm{mol} / 1$ with a 60 -fold viral load in vitro by screening various antiviral drugs. Currently, two RCCT have been initiated to evaluate the efficacy and safety of Arbidol in the treatment of COVID-19 in China.

5. Favipiravir. Favipiravir is a viral RNA polymerase inhibitor that action can be mediated by its metabolite ribofuranosyl-5' - triphosphate (RTP), which inhibits the activity of influenza virus RNA polymerase. Favipiravir was urgently used, which demonstrated a good inhibitory effect on the Ebola virus in 2014 (Senanayake, 2020). Despite its relatively modest antiviral activity, favipiravir can completely inhibit the replication of mouse norovirus (MNV) at a concentration of 100 micrograms / $\mathrm{ml}$ with or without minor side effects on cells (cell survival > 80\%) [20]. Favipiravir was officially approved by the Chinese medical products administration for marketing and officially launched into production in China. Favipiravir is the first approved drug with a potential therapeutic effect for COVID-19 in China, which will play an important role in the prevention and control of SARS-CoV-2 infection (Senanayake, 2020).

6. Remdesivir. It has a strong antiphilovirus effect in vitro and a certain anti-coronavirus effect due to the inhibition of RNA-dependent RNA synthetase in experiments on animals. Subsequent studies have shown that remdesivir is not only effective against Ebola virus, but also suppresses respiratory syncytial virus, coronavirus, Nipah virus, and Hendra virus (Devaux et al., 2020).

Researchers reported that the first patient with COVID-19 in the United States recovered after treatment with remesivir (Devaux et al., 2020). In November 2019, the results of a phase II clinical trial showed that 175 out of 681 Ebola patients were treated with remdesivir after 29 serious adverse reactions, only one of which was associated with remdesivir (Schlagenhauf et al., 2020).

Preliminary results of a clinical study conducted by the National Institute of Allergy and Infectious diseases (NIAID) in the United States showed that patients treated with remdesivir had a $31 \%$ faster recovery time than patients treated with placebo, indicating a significant positive effect of remdesivir on reducing the recovery time of patients with COVID-19 (Schlagenhauf et al., 2020). However, a randomized double-blind placebo-controlled multicenter clinical trial conducted by Chinese scientists showed that remdesivir does not accelerate recovery and does not reduce mortality in patients with severe COVID-19 compared to the placebo group. The rate of early discontinuation due to side effects, including nausea, vomiting, and cardiopulmonary failure, was higher in the remdesivir group than in the placebo group $(11.6 \%$ vs. $5.1 \%)$. Although this is the first quality clinical trial of remdesivir in the treatment of COVID-19, only 237 samples are included in the clinical 
trial. Consequently, the antiviral efficacy and safety of remdesivir still need to be confirmed by higher-quality clinical trials with larger samples (Levi et al., 2020).

7. Rapamycin. This drug is one of the new drugs offered for the treatment of COVID-19 today is rapamycin (Kalra et al., 2020). It is a macrolide immunosuppressant that inhibits mTOR. MTOR is a serine / threonine protein kinase that exists in the form of two protein complexes (mTORC1 and mTORC2) with different protein components and substrates (Kalra et al., 2020). MTORC1 is sensitive to rapamycin, as well as to environmental stimuli including amino acids, glucose, and oxygen, and is also known as a rapamycin-sensitive complex. MTORC2 acts below PI3K and is best described as an insulin / IGF-1 (insulin-like growth factor-1) signal effector (Husain \& Byrareddy, 2020) and is known as a rapamycin-insensitive complex. MTORC1 controls protein synthesis, autophagy, and many other cellular processes by phosphorylating the ribosomal protein S6, p70S6K, and 4E-BP1, whereas mTORC2 is necessary for maximum activation of many kinases, including AKT (protein kinase B) (Husain \& Byrareddy, 2020).

Target proteins, mTOR, and related rapamycin pathways are widely expressed in almost all eukaryotic organisms, and also regulate proliferation, transcription, autophagy, metabolism, and programmed cell death (Pandey et al., 2020). Based on scientific evidence and due to the involvement of mTOR in the regulation of pathways related to cellular metabolism, proliferation, aging, and immune regulation, here we describe the potential for drug reprofiling that may allow us to consider rapamycin as a drug candidate for the treatment of COVID-19 (Liu et al., 2020).

Traditional Chinese medicine products should also, in our opinion, receive more extensive study due to their ability to resist COVID-19. Chinese herbal recipes refer to a recipe consisting of two or more components for the treatment of a relatively specific disease and syndrome, which has a relatively prescribed treatment method and method of use. Each herb in the Chinese herbal compound recipe has a specific medicinal effect that interacts with each other to enhance the therapeutic effect or reduce toxicity and side effects. Recipes of Chinese herbal mixtures are widely used in clinical practice, which in general has a complex effect on the broad-spectrum antibacterial, antiviral and immune functions.

\section{Conclusion}

In a relatively short period of time, a significant amount of research has been conducted to better understand the structure of SARS-CoV-2 and the impact of this virus on human health in order to develop effective countermeasures. Using information about viral proteins, several research groups are developing vaccines and medicines. Some of these therapeutic and prophylactic drugs are currently undergoing clinical trials. It is expected that vaccines and medicines will be found that will reduce the global damage to public health caused by this virus (https://www.fda.gov).

China has some experience in the prevention and treatment of SARS-CoV-2 infection using the above-mentioned medicines, including chemicals, traditional Chinese medications and biological products. Although these drugs are expected to be specific medicines for the treatment of COVID-19, caution should be exercised when taking these drugs without sufficient evidence of their effectiveness and safety. These potential medications are currently being used to treat COVID-19 in many countries and regions due to the COVID-19 outbreak. The main characteristics of these drugs, including pharmacological effects, indications, and adverse reactions, and especially progress in the treatment of COVID-19, should be understood in order to promote reasonable medications and guide further basic research and clinical trials.

\section{References}

Coperchini, F., Chiovato, L., Croce, L., Magri, F., \& Rotondi, M. (2020). The cytokine storm in COVID-19: An overview of the involvement of the chemokine/chemokine-receptor system. Cytokine \& growth factor reviews, 53, 25-32.

Devaux, C. A., Rolain, J. M., Colson, P., \& Raoult, D. (2020). New insights on the antiviral effects of chloroquine against coronavirus: what to expect for COVID-19?. International journal of antimicrobial agents, 55(5), 105938. 
Heimfarth, L., Serafini, M. R., Martins-Filho, P. R. S., Quintans, J. S. S., \& Júnior, L. J. Q. (2020). Drug repurposing and cytokine management in response to COVID-19: A review. International Immunopharmacology, 106947.

Huang, J., Song, W., Huang, H., \& Sun, Q. (2020). Pharmacological therapeutics targeting RNAdependent RNA polymerase, proteinase and spike protein: from mechanistic studies to clinical trials for COVID-19. Journal of clinical medicine, 9(4), 1131.

Husain, A., \& Byrareddy, S. N. (2020). Rapamycin as a potential repurpose drug candidate for the treatment of COVID-19. Chemico-biological interactions, 109282.

Kalra, R. S., Tomar, D., Meena, A. S., \& Kandimalla, R. (2020). SARS-CoV-2, ACE2, and hydroxychloroquine: cardiovascular complications, therapeutics, and clinical readouts in the current settings. Pathogens, 9(7), 546.

Levi, M., Thachil, J., Iba, T., \& Levy, J. H. (2020). Coagulation abnormalities and thrombosis in patients with COVID-19. The Lancet. Haematology, 7(6), e438.

Li, G., Fan, Y., Lai, Y., Han, T., Li, Z., Zhou, P., ... \& Wu, J. (2020). Coronavirus infections and immune responses. Journal of medical virology, 92(4), 424-432.

Liu, J., Cao, R., Xu, M., Wang, X., Zhang, H., Hu, H., ... \& Wang, M. (2020). Hydroxychloroquine, a less toxic derivative of chloroquine, is effective in inhibiting SARS-CoV-2 infection in vitro. Cell discovery, 6(1), 1-4.

McGonagle, D., Sharif, K., O'Regan, A., \& Bridgewood, C. (2020). The role of cytokines including interleukin-6 in COVID-19 induced pneumonia and macrophage activation syndrome-like disease. Autoimmunity reviews, 19(6), 102537.

O. of the Commissioner Coronavirus (COVID-19) Update: FDA Issues Emergency Use Authorization for Potential COVID-19 Treatment FDA (2020) https://www.fda.gov/newsevents/press-announcements/coronavirus-covid-19-update-fda-issues-emergency-use-authorization-potential-covid-19-treatment. Accessed on the 21st Jul 2020.

Pan, X., Dong, L., Yang, N., Chen, D., \& Peng, C. (2020). Potential drugs for the treatment of the novel coronavirus pneumonia (COVID-19) in China. Virus research, 198057.

Pandey, A., Nikam, A. N., Shreya, A. B., Mutalik, S. P., Gopalan, D., Kulkarni, S., ... \& Prassl, R. (2020). Potential therapeutic targets for combating SARS-CoV-2: Drug repurposing, clinical trials and recent advancements. Life sciences, 117883.

Ragab, D., Salah Eldin, H., Taeimah, M., Khattab, R., \& Salem, R. (2020). The COVID-19 cytokine storm; what we know so far. Frontiers in immunology, 11, 1446.

Ruan, Q., Yang, K., Wang, W., Jiang, L., \& Song, J. (2020). Clinical predictors of mortality due to COVID-19 based on an analysis of data of 150 patients from Wuhan, China. Intensive care medicine, 46(5), 846-848.

Russell, B., Moss, C., George, G., Santaolalla, A., Cope, A., Papa, S., \& Van Hemelrijck, M. (2020). Associations between immune-suppressive and stimulating drugs and novel COVID-19-a systematic review of current evidence. ecancermedicalscience, 14.

Schlagenhauf, P., Grobusch, M. P., Maier, J. D., \& Gautret, P. (2020). Repurposing antimalarials and other drugs for COVID-19. Travel medicine and infectious disease, 34, 101658.

Senanayake, S. L. (2020). Drug repurposing strategies for COVID-19.

Snijder, E. J., Van Der Meer, Y., Zevenhoven-Dobbe, J., Onderwater, J. J., Van Der Meulen, J., Koerten, H. K., \& Mommaas, A. M. (2006). Ultrastructure and origin of membrane vesicles associated with the severe acute respiratory syndrome coronavirus replication complex. Journal of virology, 80(12), 5927-5940.

Ulhaq, Z.S. (2020). SorayaInterleukin-6 as a potential biomarker of COVID-19 progression Med. Mal. Infect., 50, 382-383.

Xia, S., Liu, M., Wang, C., Xu, W., Lan, Q., Feng, S., ... \& Lu, L. (2020). Inhibition of SARS-CoV2 (previously $2019-\mathrm{nCoV}$ ) infection by a highly potent pan-coronavirus fusion inhibitor targeting its spike protein that harbors a high capacity to mediate membrane fusion. Cell research, 30(4), 343-355.

Xu, Z., Shi, L., Wang, Y., Zhang, J., Huang, L., Zhang, C., ... \& Wang, F. S. (2020). Pathological findings of COVID-19 associated with acute respiratory distress syndrome. The Lancet respiratory medicine, 8(4), 420-422.

Ye, Q., Wang, B., \& Mao, J. (2020). The pathogenesis and treatment of theCytokine Storm'in COVID-19. Journal of infection, 80(6), 607-613. 
Zang, R., Castro, M. F. G., McCune, B. T., Zeng, Q., Rothlauf, P. W., Sonnek, N. M., ... \& Ding, S. (2020). TMPRSS2 and TMPRSS4 promote SARS-CoV-2 infection of human small intestinal enterocytes. Science immunology, 5(47).

Zhang, C., Wu, Z., Li, J. W., Zhao, H., \& Wang, G. Q. (2020). Cytokine release syndrome in severe COVID-19: interleukin-6 receptor antagonist tocilizumab may be the key to reduce mortality. International journal of antimicrobial agents, 55(5), 105954.

Zhang, L., Yan, X., Fan, Q., Liu, H., Liu, X., Liu, Z., \& Zhang, Z. (2020). D-dimer levels on admission to predict in-hospital mortality in patients with Covid-19. Journal of Thrombosis and Haemostasis, 18(6), 1324-1329.

Zhou, F., Yu, T., Du, R., Fan, G., Liu, Y., Liu, Z., ... \& Cao, B. (2020). Clinical course and risk factors for mortality of adult inpatients with COVID-19 in Wuhan, China: a retrospective cohort study. The lancet, 395(10229), 1054-1062. 